\title{
GEOECOLOGICAL ENVIRONMENTAL EVALUATION OF PAVLODAR REGION OF THE REPUBLIC OF KAZAKHSTAN AS A FACTOR OF PERSPECTIVES FOR TOURISTIC ACTIVITY
}

\author{
Galymbek AZHAYEV \\ S. Toraigyrov Pavlodar State University, Department of Geography and Tourism, \\ Lomov Str., 64, 140000 Pavlodar, Republic of Kazakhstan, e-mail: agalymbek@mail.ru

\section{Dinara ESIMOVA} \\ S. Toraigyrov Pavlodar State University, Department of Geography and Tourism, \\ Lomov Str., 64, 140000 Pavlodar, Republic of Kazakhstan, e-mail: dika-73@mail.ru

\section{Seedou Mukthar SONKO} \\ Assane SECK University of Ziguinchor, TRU of Economic \& Social Sciences, \\ Department of Tourism, Senegal, e-mail: sm.sonko@univ-zig.sn

\section{Ruslan SAFAROV*} \\ L.N. Gumilyov Eurasian National University, Faculty of Natural Sciences, Satpayev \\ Str., 2, 010008 Nur-Sultan, Republic of Kazakhstan, e-mail: ruslanbox@yandex.ru

\section{Zhanat SHOMANOVA} \\ Pavlodar State Pedagogical University, Department of Geography and Chemistry, \\ Mira Str., 60, 14000o Pavlodar, Republic of Kazakhstan, e-mail: zshoman@yandex.ru
}

\author{
Alphonse SAMBOU \\ Assane SECK University of Ziguinchor, TRU of Economic \& Social Sciences, \\ Department of Tourism, Senegal, e-mail: asambou@univ-zig.sn
}

\begin{abstract}
Citation: Azhayev G., Esimova D., Sonko S.M., Safarov R., Shomanova Zh. \& Sambou A. (2020). GEOECOLOGICAL ENVIRONMENTAL EVALUATION OF PAVLODAR REGION OF THE REPUBLIC OF KAZAKHSTAN AS A FACTOR OF PERSPECTIVES FOR TOURISTIC ACTIVITY. GeoJournal of Tourism and Geosites, 28(1), 104-113. https://doi.org/10.30892/gtg.28108-4.55
\end{abstract}

\begin{abstract}
It is well known that condition of environment is one of the most significant factors affecting the perspectives for tourism in the region. So, when we are considering ways of tourism development in such industrial cities as Pavlodar, usually we have to describe environmental conditions in the region. Thus, the main aim of the research is to reveal ecological characteristics of industrial city Pavlodar as a touristic region. The main methods used in the research are environmental risks analysis, elemental analysis of soils and snow, GIS. On the territory of Pavlodar region the industry is concentrated in the center of 3 industrial units - in such cities as Pavlodar, Ekibastuz, and Aksu. Enterprises of these centers are the main air pollutants; it is $99.3 \%$ of all industrial emissions of the territories. The possibility of using geochemical data on the content of microelements in soils and snow cover for
\end{abstract}


zoning the territory of Pavlodar is shown in this article. According to the classification of Yu.V. Sayet snow cover of central area in Pavlodar refers to the average moderately dangerous levels of pollution; the northern and eastern industrial zones refer to a dangerously high pollution. Researches of soil cover showed soil in residential zones and zones of northern suburbs belong to an acceptable level of pollution, soil in eastern and northern industrial zones belong to a high level of pollution. Evaluation of anthropogenic impact on natural complexes of the region, including the Irtysh River, is given. Regulation of runoff of the Irtysh River cascade of reservoirs in the upper reaches by short and untimely release of water has led to a change in bioproductivity, abundance and species composition of phytocenoses. External water filling floodplains, not associated with the dissolved soil humus, on the contrary, they contribute to the accelerated migration of acids and intense growth and development of meadow grasses. With the cessation of seasonal bays mode soil skewed towards reducing the activity of the process. It was concluded that ecological condition of the considered region can negatively affect on the tourism intensity of the region.

Key words: Pavlodar, industrial load, tourism intensity, tourism perspectives, ecotourism, touristic attractiveness, floodplain, Irtysh river

$* * * * * *$

\section{INTRODUCTION}

Pavlodar region is one of the most economically developed regions of the Republic of Kazakhstan which has a strategic importance for the country. The Pavlodar region has a lot of touristic places and can attract tourists from other cities and countries. The Irtysh river is on of the biggest rivers of Eurasia. The Bayan-aul rocks are unique in Kazakhstan and have some endemic species of flora. The nature of Bayan-aul is very attractive for tourists from the whole world. Unfortunately, being the significant industrial center of Kazakhstan the Pavlodar region has different problems inherent to industrial cities. It is well known, that industrial cities have different negative consequences for touristic activity because of environment condition (Badiali et al., 2018). Significant number of researchers sign, that the expansion of tourism translates into an environmental deterioration of the destination and, furthermore, it substantiates that there are specific variables connected to environmental sustainability that contribute to greater tourism growth, so that the relationship between tourism and environmental sustainability is bidirectional (Pulido-Fernández et al., 2019). Other study confirmed the feedback relationship between tourism income and energy demand, as well as between $\mathrm{CO}_{2}$ emissions and international tourism departures, while study supported the growth-led tourism income across countries (Shaheen et al., 2019). Key environmental issues of Pavlodar region are air pollution, soil and environmental problems of the Irtysh River and its floodplain. Fifth part of all emissions of polluting substances into the atmosphere in Kazakhstan takes Pavlodar region, the environmental situation is characterized as tense. A researched region has high anthropogenic pollution, the field of basic industries here are mining, oil refining and chemical industry, ferrous and non-ferrous metallurgy, energetics. In the region until 1991 there was Semipalatinsk nuclear polygon (39\% of its territory is located on the lands of Mayskiy district of Pavlodar region). The region has a significant fleet of mobile sources of air pollution (Nugumanova et al., 2017).

In Pavlodar region more than 200 large enterprises that use natural carrying emissions from 3880 sources are registered. According to the territory of the bulk of emissions belong to industrial enterprises that are located in the cities of Pavlodar 
Galymbek AZHAYEV, Dinara ESIMOVA, Seedou Mukthar SONKO, Ruslan SAFAROV, Zhanat SHOMANOVA, Alphonse SAMBOU

region: Ekibastuz, Aksu and Pavlodar. The bulk of industrial emissions of Pavlodar region come from thermal energetics and metallurgical industries (Nugumanova et al., 2017). It is well known that industries depending on their capacity and production characteristics can influence on the change of geochemical features of the territories on the local level and on the regional and global scales as well.

Chemical elements are distributed in the environment and are included in the natural course of global, regional biogeochemical cycles (Négrel et al., 2019). The main source of drinking water for the residents of Pavlodar region is a transboundary river Irtysh, which is characterized as moderately polluted. Contaminants come mainly from the enterprises of the East Kazakhstan region. Misbalance between the anthropogenic load on water objects and their capacity to renovation led to the fact that ecological trouble was characterized by almost the entire region.

\section{MATERIALS AND METHODS}

In geochemical researches of the environment, along with certain chemical elements, the distribution of chemical elements associations was analyzed (Grizzetti et al., 2019). Quantitative measure of association is the total pollution index, representing the excess amount of the additive concentration factors (scattering) over the unit (background) level (Berdenov et al., 2017). Total indicators of pollution are calculated for different landscape components - soil, snow. Analysis of distribution of geochemical parameters derived from sampling of snow cover and soil on a regular grid, gives the spatial structure of residential areas and pollution of air basin with the greatest risk to health of population (Mendybayev et al., 2015).

Total indicator of pollution $\left(Z_{c}\right)$, which was conducted by zoning, was proposed by $\mathrm{Yu}$. E. Sayet and represents the additive amount of the excess concentration coefficients (scattering) over the unit (background) level (Sayet et al., 1990).

$$
Z_{c}=\sum_{1}^{i} \frac{C_{i}-C_{p}}{C_{p}}+1=\sum_{1}^{n} K_{c}-(n-1),
$$

where $K_{c}$ is a concentration factor (ratio of the chemical element in the estimated object to its content background, $n$ is the number of chemical elements in the studied association, $C_{i}$ is an anomalous content, $C_{p}$ is a content background.

Total indicators of pollution are calculated for the various components of the landscape - soil, snow. This indicator can be defined as for keeping in a separate sample, and for the part of territory (district, functional area, focus halo). In the latter case, the research is conducted in geochemical samples (Khomyakov, 2011).

Evaluation of risk of soil pollution by complex of elements in terms of $Z_{c}$ is held on an assessment scale, gradations of which are based on the study of health outcomes of people living in areas with different levels of soil contamination (Table 1).

Table 1. Approximate rating scale of pollution risks of snow and soil according to total pollution index (Sayet et al., 1990)

\begin{tabular}{|l|l|l|}
\hline \multicolumn{1}{|c|}{ Level of pollution } & \multicolumn{1}{c|}{ Quantity $Z_{c}$} & \multicolumn{1}{c|}{ Quantity $Z_{c}$} \\
\hline Allowable & Less than 64 & Less than 16 \\
\hline Average moderately dangerous & $64-128$ & $16-32$ \\
\hline Highly dangerous & $128-256$ & $32-128$ \\
\hline Very high and extremely dangerous & More than 256 & More than 128 \\
\hline
\end{tabular}


Each sample may be presented as a set of relative features of abnormality of chemical elements. This set allows giving a qualitative and quantitative evaluation of the geochemical association of the researched object. The development of complex regional directions of lowland natural systems research for sustainable development of the region requires the search for new methodological techniques. One such method is a systematic approach as a way to realization of the law of dialectics about the relationship and interaction of objects and phenomena. The main issue here is the complex of methodological principles of analysis and construction of an object as a system - a holistic set of interrelated elements considered at a certain point of view.

A system analysis is the analysis of complex, whole, undivided in the context of the intended target. In connection with this, a systematic analysis is specific way of knowledge of the phenomena and processes occurring in the studied objects. Variety of natural and economic objects forms real, objectively existing systems. However, in solving various practical problems, it is difficult and sometimes impractical to cover all relationships equally. Hence, on the one natural object many systems can be constructed. Nowadays a systematic approach is probably the only way that allows at the methodological level to look for approaches to linking private geo-environmental issues. One of the leading approaches of systematic analysis of the functioning of the valley complexes can be noted are a landscape and a basin (Theng et al., 2014).

Formation of valley paragenetic hydromorphic landscape complexes largely predetermined by geological and geomorphological and hydrological factors and inherently reflect the characteristics of the ancient and modern functioning of paragenesis of basin geosystems. Using the basin landscape approach in the study of these features and allows to have a comprehensive approach to the study of geo-ecological assessment of the object and to solve environmental problems, in particular the development of water protection objectives, modeling of hydromorphic geosystems (Nworie et al., 2019).

\section{RESULTS DISCUSSIONS}

On the territory of Pavlodar region, the industry is concentrated in the center of 3 industrial units - in such cities as Pavlodar, Ekibastuz, and Aksu.

Enterprises of these centers are the main air pollutants; it is $99.3 \%$ of all industrial emissions of the territories. The contribution of each of the cities (Pavlodar, Ekibastuz and Aksu) according to the amount of pollutants emissions into the atmosphere is not the same (28.6, 38.3 and $33.1 \%$, respectively) (Table 2 ).

Table 2. Emissions of pollutants into the atmosphere in the cities of Pavlodar region in 2011-2012 (according to the Newsletter in the environmental state in the Republic of Kazakhstan for 2011/2012)

\begin{tabular}{|l|c|c|c|}
\hline $\begin{array}{c}\text { Cities of the } \\
\text { region }\end{array}$ & $\begin{array}{c}\text { Amount of emission } \\
\text { in 2011, thousand tons }\end{array}$ & $\begin{array}{c}\text { Amount of emission } \\
\text { in 2012, thousand tons }\end{array}$ & $\begin{array}{c}\text { Increase of emission relatively } \\
\text { to 2011, thousand tons }\end{array}$ \\
\hline Pavlodar & 160.5 & 168.4 & +7.9 \\
\hline Ekibastuz & 200.6 & 225.1 & +24.6 \\
\hline Aksu & 187.0 & 194.9 & +7.9 \\
\hline Pavlodar region & 548.1 & 588.4 & +40.4 \\
\hline
\end{tabular}

Research of the solid constituents of exhaust gases showed a significant difference in their chemical composition, including the content of chemical elements. For example, the emissions related to Company Profile of Pavlodar Heat Electro power Station 1,2 and State District Power Station in Aksu aluminum content varies 2.5 times (o.59 and 0.23 
Galymbek AZHAYEV, Dinara ESIMOVA, Seedou Mukthar SONKO,

Ruslan SAFAROV, Zhanat SHOMANOVA, Alphonse SAMBOU

$\mathrm{mg} / \mathrm{g}$ ), copper - 7 times ( 0.03 and $0.004 \mathrm{mg} / \mathrm{g}$ ), titanium - 60 times $(0.3$ to $0.005 \mathrm{mg} / \mathrm{g}$ ), lead - 3 times ( 0.009 and $0.003 \mathrm{mg} / \mathrm{g}$ ), iron - 4 times ( 0.13 and $0.03 \mathrm{mg} / \mathrm{g}$ ), respectively (PavlodarEnergo, Annual report, 2013). Depending on the particle size, they are deposited at different distances from the source, and then, according to a rational and chemical composition can leach, migrate to a considerable distance and being deposited, concentrate on different parts of territorial industrial complex area.

Daily dust load in Pavlodar and suburbs (Fig. 1) up to 15 times higher than the background rate $\left(9.75 \mathrm{~kg} / \mathrm{km}^{2} / 24 \mathrm{~h}\right)$ loss of aerosol particles for continental plains areas of temperate latitudes. In industrial zones high dust pollution within 8-13 times higher than the background. A characteristic feature of pollutants in Pavlodar is multicomponent. During our research characteristics of geochemical specialization of different areas of the region have been obtained (Tables 5-7).

According to the classification of Yu.V. Sayet (Sayet et al., 1990) snow cover of central area in Pavlodar refers to the average moderately dangerous levels of pollution, the northern and eastern industrial zones refer to a dangerously high pollution. On average, the aqueous snow phase in Pavlodar is characterized by mercury-copper, copper-cadmium and copper-lead geochemical specialization (Table 3).

Table 3. Comparative characteristics of individual areas of the water fraction of snow pollution in Pavlodar $\left(Z_{c}\right)$

\begin{tabular}{|c|c|c|c|}
\hline \multirow{2}{*}{$\begin{array}{l}\text { Area of } \\
\text { pollution }\end{array}$} & \multicolumn{2}{|c|}{ Level of $Z_{c}$} & \multirow{2}{*}{$\begin{array}{c}\text { Formula of geochemical } \\
\text { specialization }\end{array}$} \\
\hline & Fluctuation limit & On average areal & \\
\hline $\begin{array}{l}\text { Northern } \\
\text { Industrial Zone }\end{array}$ & $10.5-711.2$ & 249.3 & $\begin{array}{l}\mathrm{Hg}_{109.4} \mathrm{Cu}_{42.4} \mathrm{~Pb}_{31.5} \mathrm{Ni}_{13.0} \mathrm{Cd}_{11.1} \mathrm{Be}_{10.5} \mathrm{~V}_{9.9} \\
\mathrm{Sr}_{8.3} \mathrm{Mo}_{6.8} \mathrm{Cr}_{6.4} \mathrm{Mn}_{4.7} \mathrm{Co}_{3.9} \mathrm{Zn}_{3.6}\end{array}$ \\
\hline $\begin{array}{l}\text { Eastern } \\
\text { Industrial Zone }\end{array}$ & $3.19-720.3$ & 235.2 & $\begin{array}{l}\mathrm{Cu}_{81.3} \mathrm{Cd}_{55.7} \mathrm{~Pb}_{52.8} \mathrm{Ni}_{9.9} \mathrm{Mo}_{8.8} \mathrm{Mn}_{8.0} \mathrm{Cr}_{6.7} \\
\mathrm{Sr}_{4.9} \mathrm{Hg}_{4.7} \mathrm{Zn}=\mathrm{Co}_{4.3} \mathrm{~V}_{3.3} \mathrm{Be}_{2.6}\end{array}$ \\
\hline $\begin{array}{l}\text { Central } \\
\text { (residential) Zone }\end{array}$ & $29 \cdot 3-74.6$ & 53.6 & $\begin{array}{l}\mathrm{Cu}_{12.8} \mathrm{~Pb}_{9.6} \mathrm{Ni}_{7.9} \mathrm{Cr}_{5.6} \mathrm{Mn}_{5.3} \mathrm{~V}_{4.7} \mathrm{Cd}_{3.6} \mathrm{Mo}_{3.4} \\
\mathrm{Zn}_{3.1 \mathrm{~S}} \mathrm{Sr}=\mathrm{Hg}_{2.8} \mathrm{Co}_{2.5} \mathrm{Be}_{1.7}\end{array}$ \\
\hline $\begin{array}{l}\text { Total in } \\
\text { the city }\end{array}$ & $3.19-720.3$ & 179.4 & $\begin{array}{l}\mathrm{Hg}_{60.1} \mathrm{Cu}_{48.9} \mathrm{~Pb}_{34.1} \mathrm{Cd}_{23.1} \mathrm{Ni}_{11.2} \mathrm{~V}_{7.0} \mathrm{Mo}_{6.8} \\
\mathrm{Be}_{6.6} \mathrm{Sr}_{6.4} \mathrm{Cr}_{6.3} \mathrm{Mn}_{5.8} \mathrm{Co}_{3.8} \mathrm{Zn}_{3.7}\end{array}$ \\
\hline
\end{tabular}

In the northern industrial zone Z-forming metals of water fraction of snow cover are mercury, copper, lead; in the eastern industrial zone - copper, cadmium, lead; central - copper, lead, nickel, chromium and manganese.

Table 4. Comparative characteristics of individual areas of the solid fraction of snow pollution in Pavlodar (Zc)

\begin{tabular}{|c|c|c|c|}
\hline \multirow[b]{2}{*}{ Area of pollution } & \multicolumn{2}{|c|}{ Level of $Z_{c}$} & \multirow[b]{2}{*}{ Formula of geochemical specialization } \\
\hline & $\begin{array}{c}\text { Fluctuation } \\
\text { limit }\end{array}$ & $\begin{array}{l}\text { On average } \\
\text { areal }\end{array}$ & \\
\hline $\begin{array}{l}\text { Northern } \\
\text { Industrial Zone }\end{array}$ & $18.5^{-184.1}$ & 83.6 & $\begin{array}{l}\mathrm{Cd}_{14.9} \mathrm{Be}_{13.9} \mathrm{Sr}_{11.4} \mathrm{Mo}=\mathrm{Cu}_{7.9} \mathrm{Mn}_{7.3} \mathrm{~V}_{6.6} \mathrm{Co}_{6.2} \\
\mathrm{Zn}_{6.0} \mathrm{~Pb}_{4.8} \mathrm{Ni}_{4.4} \mathrm{Cr}_{3.4}\end{array}$ \\
\hline $\begin{array}{l}\text { Eastern Industrial } \\
\text { Zone }\end{array}$ & $3.8-163.7$ & 66.2 & $\begin{array}{l}\mathrm{Cd}_{14.1} \mathrm{Mn}_{8.8} \mathrm{Mos}_{.6} \mathrm{Be}_{.0} \mathrm{Sr}_{7.2} \mathrm{Cu}_{6.6} \mathrm{Zn}_{5.4} \mathrm{~Pb}_{4.6} \\
\mathrm{~V}_{4.4} \mathrm{Co}_{4.0} \mathrm{Ni}_{2.8} \mathrm{Cr}_{2.7}\end{array}$ \\
\hline $\begin{array}{l}\text { Central } \\
\text { (residential) Zone }\end{array}$ & $41.3-71.0$ & 58.5 & $\begin{array}{l}\mathrm{Zn}_{25.3} \mathrm{Be}_{7.1} \mathrm{Co}=\mathrm{V}_{4.7} \mathrm{Cd}_{4.6} \mathrm{Sr}_{4.3} \mathrm{Mo}_{3.8} \mathrm{Mn}_{3.3} \\
\mathrm{Cu}_{3.2} \mathrm{Ni}_{3.1} \mathrm{~Pb}_{3.0} \mathrm{Cr}_{2.5}\end{array}$ \\
\hline Total in the city & $3.8-184.1$ & 69.4 & $\begin{array}{l}\mathrm{Cd}_{13.2} \mathrm{Be}_{11.1} \mathrm{Sr}_{9.1} \mathrm{Mo}_{7.6} \mathrm{Mn}_{7.1} \mathrm{Cu}_{6.8} \mathrm{~V}_{5.7} \mathrm{Zn}_{5.6} \\
\mathrm{Co}_{5.3} \mathrm{~Pb}_{4.5} \mathrm{Ni}_{3.7} \mathrm{Cr}_{3.1}\end{array}$ \\
\hline
\end{tabular}


As enterprises form territorial industrial sites in the city, spots of pollutions have more than one center, which has the maximum content in the snow of a particular element, and several centers, different composition of elements accumulated in the intensity of their accumulation (Shomanova et al., 2017).

Average level of $Z_{c}$ in the aqueous fraction of snow is 33.1. The solid fraction of the snow cover in Pavlodar is typical to cadmium-beryllium, cadmium manganese and zinc beryllium geochemical of specialization (Table 4).

In the northern industrial zone Z-forming metals are cadmium, beryllium, strontium; the eastern industrial zone - cadmium, manganese, molybdenum; central cadmium, beryllium, strontium (Shomanova et al., 2014).

The average level of $Z_{\mathrm{c}}$ for the specified zone is 34 .

Researches of soil cover showed that according to the classification of Sayet soil in residential zones and zones of northern suburbs belong to an acceptable level of pollution, soil in eastern and northern industrial zones belong to a high level of pollution. On average, soil in Pavlodar is typical to cadmium - mercury -cadmium and strontium geochemical specialization (Table 5).

Table 5. Comparative characteristics of individual areas of soil pollution in Pavlodar

\begin{tabular}{|c|c|c|c|}
\hline \multirow{2}{*}{ Area of pollution } & \multicolumn{2}{|c|}{ Level of $Z_{c}$} & \multirow{2}{*}{$\begin{array}{c}\text { Formula of geochemical } \\
\text { specialization }\end{array}$} \\
\hline & Fluctuation limit & On average areal & \\
\hline $\begin{array}{l}\text { Northern } \\
\text { Industrial Zone }\end{array}$ & $4.9-256.5$ & 69.3 & $\begin{array}{l}\mathrm{Hg}_{42.3} \mathrm{Cd}_{13.8} \mathrm{Sr}_{7.8} \mathrm{~Pb}_{3.4} \mathrm{Zn}=\mathrm{Mo}_{1.8} \mathrm{Ni}_{1.3} \\
\mathrm{Cu}=\mathrm{V}_{1.2} \mathrm{Co}_{1.0} \mathrm{Cr}_{0.9} \mathrm{Mn}_{0.8} \mathrm{Be}_{0.7}\end{array}$ \\
\hline $\begin{array}{l}\text { Eastern } \\
\text { Industrial Zone }\end{array}$ & $10.7-108.1$ & $44 \cdot 7$ & $\begin{array}{l}\mathrm{Cd}_{26.2} \mathrm{Sr}_{5.5} \mathrm{~Pb}_{5.2} \mathrm{Mo}_{3.6} \mathrm{Hg}_{2.7} \mathrm{Zn}_{2.1} \mathrm{Cr}= \\
\mathrm{Co}_{1.8} \mathrm{Cu}_{1.6} \mathrm{~V}_{1.2} \mathrm{Mn}=\mathrm{Ni}_{1.1} \mathrm{Be}_{1.0}\end{array}$ \\
\hline $\begin{array}{l}\text { Central } \\
\text { (residential) Zone }\end{array}$ & $8.3-26.8$ & 19.4 & $\begin{array}{l}\mathrm{Cd}_{9.3} \mathrm{Sr}_{6.2} \mathrm{~Pb}_{2.9} \mathrm{Mo}_{2.3} \mathrm{Hg}_{1.9} \mathrm{Zn}_{1.1} \mathrm{Cu}=\mathrm{Cr}_{1.0} \\
\mathrm{Co}=\mathrm{Ni}_{0.9} \mathrm{~V}=\mathrm{Mn}_{0.8} \mathrm{Be}_{0.4}\end{array}$ \\
\hline Total in the city & $4.1-19.1$ & 9.8 & $\begin{array}{l}\mathrm{Sr}_{6.0} \mathrm{Cd}_{4.9} \mathrm{Hg}_{2.6} \mathrm{~Pb}_{1.8} \mathrm{Mo}_{1.5} \mathrm{Ni}_{0.8} \mathrm{Zn}= \\
\mathrm{Mn}=\mathrm{V}_{\text {o. }} \mathrm{Cr}=\mathrm{Co}_{0.6} \mathrm{Cu}_{0.5} \mathrm{Be}_{0.2}\end{array}$ \\
\hline $\begin{array}{l}\text { Northern } \\
\text { Industrial Zone }\end{array}$ & $4.1-256.5$ & 48.2 & $\begin{array}{l}\mathrm{Cd}_{13.5} \mathrm{Hg}_{12.4} \mathrm{Sr}_{6.4} \mathrm{~Pb}_{3.3} \mathrm{Mo}_{2.3} \mathrm{Zn}_{1.4} \mathrm{Cu}= \\
\mathrm{Co}=\mathrm{Cr}_{1.1} \mathrm{Ni}=\mathrm{V}_{1.0} \mathrm{Mn}_{0.8} \mathrm{Be}_{0.6}\end{array}$ \\
\hline
\end{tabular}

In the northern industrial zone Z-forming metals are mercury, cadmium, strontium, lead; eastern - cadmium, strontium, lead, molybdenum, mercury, zinc; central - cadmium, strontium, lead, molybdenum; northern suburbs - strontium, cadmium and mercury. These data show that in the soil exposed to pressure of industrial enterprises, accumulates mostly the same heavy metals (cadmium, strontium, mercury).

The distribution of heavy metals in soils of the city a clear zonation is mentioned, reflected in a reduction of the spectrum toxicants and decrease of their concentrations with increasing distance from major sources of pollution (Dzhanaleyeva et al., 2017).

The highest concentrations of chemical elements in the soil cover of the eastern and northern areas of the city due to the fact that they are concentrated and large industrial Heat Electorpower Station. These zones are characterized by high levels of dust (more than $146.3 \mathrm{~kg} / \mathrm{km}^{2}$ in 24 hours) and natural inflow of chemical elements with atmospheric dust. Thus, only aluminum and oil-processing factories and three Heat Electorpower Stations of the city more than 126.2 tons of pollutants are emitted (from 130.5 tonnes in the whole city from stationary sources) (PavlodarEnergo, Annual report, 2013).

Maps-schemes of the total contamination coefficient $\left(Z_{c}\right)$ in water, solid fractions of snow cover and soil in the city of Pavlodar are presented in Figures 1 and 2. 
Galymbek AZHAYEV, Dinara ESIMOVA, Seedou Mukthar SONKO, Ruslan SAFAROV, Zhanat SHOMANOVA, Alphonse SAMBOU

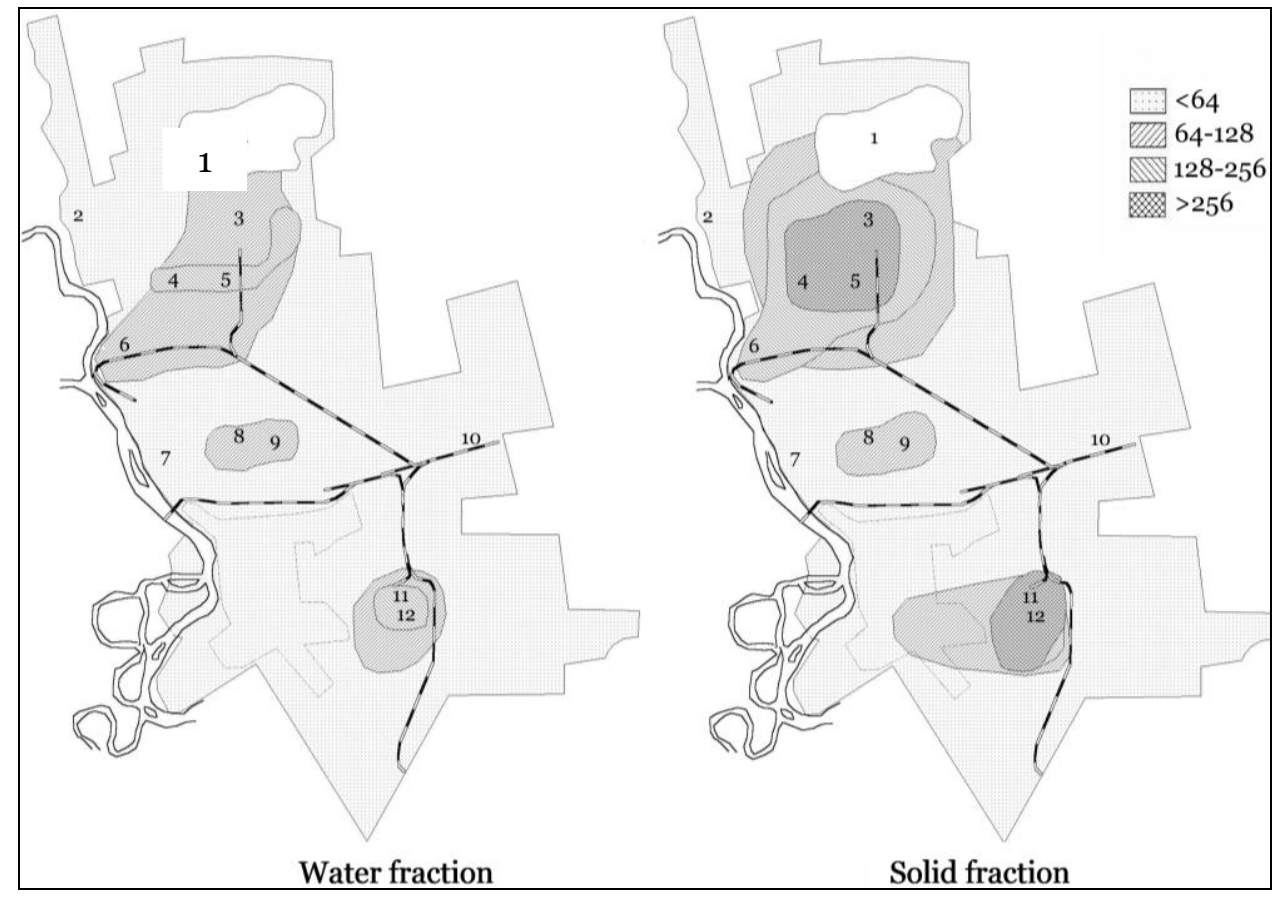

Figure 1. Map-scheme of the total contamination coefficient $\left(\mathrm{Z}_{\mathrm{c}}\right)$ in water, solid fractions of snow cover in Pavlodar (mg/kg). 1 - sump of Balkyldak lake; 2 - Pavlodarskoe village; 3 - Pavlodar chemical plant; 4 - Pavlodar petrochemical plant; 5 - CHP-3;

6 - Zhana-aul village; 7 - Lesozavod village; 8 - Pavlodar tractor plant; 9 - CHP-2; 10 - Zhetekshi village; 11 - Pavlodar aluminum plant; 12 - CHP-1

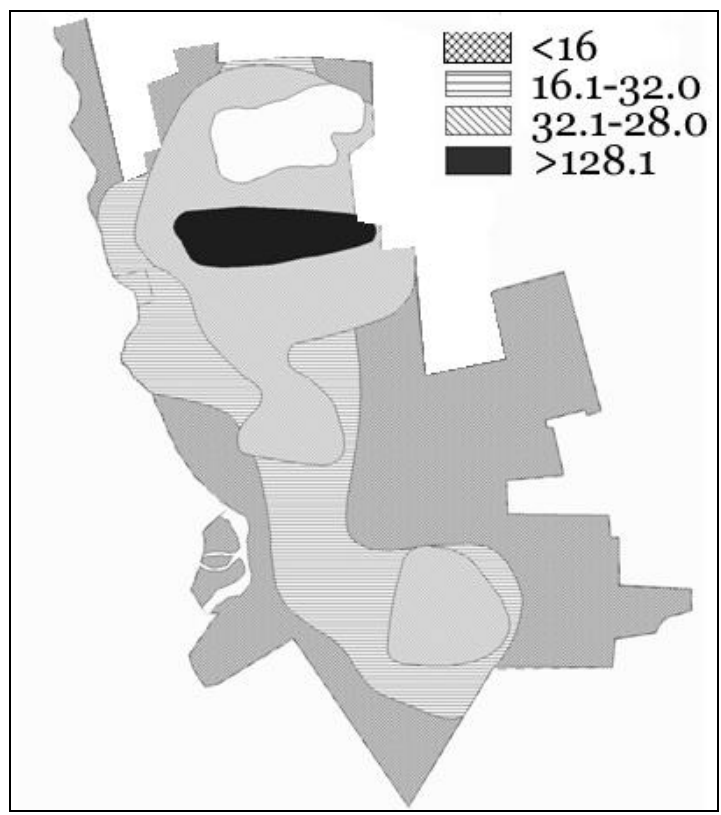

Figure 2. Map-scheme of the total contamination coefficient (Zc) in soil in Pavlodar (mg/kg) 
Hydrochemical regime in the upper flows of the Irtysh (Black Irtysh, Buran village) formed by leaching and dissolution of rocks, surface runoff from the catchment area and pollutants entering the drain of the river from the region of the China.

In the area of Ust-Kamenogorsk and downstream, under the influence of sewage discharge from the East Kazakhstan industrial complex into the Irtysh River and its tributaries, the level of pollution in the river on certain indicators increases. Surface water is the most contaminated by the following pollutants: $\mathrm{Cu}$ (2.1-6.o MPC), $\mathrm{Zn}$ (1.08.o MPC), phenol (0.4-4.0 MPC), petroleum (1.48-7.6 MPC). In the period from 1961 to 2000 average water salinity ranged $142.0-230.2 \mathrm{mg} / \mathrm{l}$, in some years - up to $316.6 \mathrm{mg} / \mathrm{l}$, i.e. there was an increase in salinity 1.1-1.7 times compared with the natural range (100$160 \mathrm{mg} / \mathrm{l})$. Fluctuations in sulphate and chloride practically correspond to fluctuations of salinity, the maximum concentration of $\mathrm{SO}_{4}$ and $\mathrm{Cl}$ was observed in dry years (19621984). And it was 30.5-42.5 and $20.4-14.4 \mathrm{mg} / \mathrm{ml}$, respectively.

The relative content of $\mathrm{HCO}_{3}$ varied within $17-38 \%$ eq. There was a dramatic increase in the total iron in 1.7-4.5 times (0.52-1.36 mg/l). The nitrate content increased 7 times in comparison to the natural range (Bobylev et al., 2016; Vaganova \& Kovalchuk, 2012; Perelman \& Kasimov, 1999; Kabiyev et al., 2018). Subgeosystem of the Irtysh River basin is a combination of interfaces and autonomous subordinates landscapes located in the same basin runoff on different hypsometric levels and flows related to substances moving from higher to lower levels. Floodplain of the Irtysh River is natural self-regulating mechanism, it is unique in its size, and in phytocenoses in subgeosystem. Floodplains in arid conditions of Pavlodar region are especially valuable because they allow to stabilize prey animal husbandry and beneficial to the local climate. Rich phytocenose of floodplain meadows of the Irtysh River is a geochemical barrier that prevents delivery of airspace sebaceous and smoke emissions of the industrial enterprises of the East Kazakhstan and Pavlodar regions, and of groundwater and surface water, pollutants and toxic substances.

In addition, the floodplain is a natural protective barrier, reducing the degree of soil erosion. Currently, the lack of funds allocated for the development of forestry, leads to the degradation of shelterbelts, reclamation activities are not conducted. Practically organic and mineral fertilizers (even for vegetable crops) were stopped. The use of irrigated lands is being reduced. Phytocenotic diversity of meadows provided greater stability of yield, especially under changing climatic conditions. Keeping quality of the floodplain landscape and all living creatures on them from time immemorial contributed cyclical seasonal flooding, which significantly disrupted today.

Regulation of runoff of the Irtysh River cascade of reservoirs in the upper reaches by short and untimely release of water has led to a change in bio-productivity, abundance and species composition phytocenoses. External water filling floodplains, not associated with the dissolved soil humus, on the contrary, they contribute to the accelerated migration of acids and intense growth and development of meadow grasses. With the cessation of seasonal bays mode soil skewed towards reducing the activity of the process.

It is known that in natural conditions the Irtysh River floodplain is flooded almost every year for $89-97 \%$ of its area, in some years, a frequency of 1 time every 6-8 years floodplain flooded only by $60-70 \%$ and a frequency of 1 time every $12-15$ years flooding amounted to $10 \%$ of the area. In wet years floodplain river flooded the entire area and sufficient for an extended period. Total flooding floodplain had a positive impact on the functioning of the unique ecosystem, as these conditions are periodically flooded areas of the floodplain with high marks, thus hindering their drainage and degradation. In addition, under such circumstances, there is a natural flushing channels numerous 
channels, oxbows and lakes, as well as waterlogged and saline areas. Yields meadow grasses in natural conditions flooding floodplain averaged 16-18 c/ha, and the most valuable wheat and ribbon grass meadows to 50-60 c/ha. During the construction period of Bukhtarma Hydroelectric Power Station (1958-1963) the Irtysh River floodplain has not flooded, causing quantitative and qualitative changes in plant communities and a sharp decrease in the yield of meadows to $5.5 \mathrm{t} / \mathrm{ha}$. Under the conditions of flow regulation, since 1964, in order to maintain the productivity of the floodplains of the cascade of reservoirs made special natural hold releases, which, according to the Committee of Ecology of Pavlodar, conducted serious violations "human exploitation cascade of Upper Irtysh reservoirs" and did not consider the needs of in the water of the river ecosystem, fisheries, shipping, etc. This led to the fact that the Irtysh River, its resources, fauna and flora ecosystems appeared in condition requiring immediate action to restore the natural resource potential of the complex.

Value of flood waters (oxbows, backwaters, creeks) is exceptionally favorable conditions for the fish fauna (Berdenov et al., 2016). Changing of the height of floodwater standing, the intensity of rise and fall of water, the duration of standing water on the floodplain led to a sharp decrease in fish production ponds and the Irtysh floodplain.

\section{CONCLUSION}

The unfavorable factors of anthropogenic load on floodplain include human intervention associated with plowing, logging, taking sand from the riverbed, creating a basin irrigation system in the floodplain, residential areas and industrial enterprises located in close proximity to the river.

Heavy metal pollution upstream and upper tributaries of the Irtysh River lead to contamination of the entire river system and the river flow. Speed, intensity and morphology of man-made landscape of migration depend on conditions such as: specificity combination meteorological and soil-botanical characteristics of the studied area. According to many authors, the main source (supplier) of heavy metals in transaccumulative, superaqueous and aquatic landscapes is superficial (not streamflow) stock. It is formed due to soil erosion, dust flush with man-made surfaces, solid-phase deposition from the atmosphere, erosion area landfills, slime pit, etc.

Thus, unfavourable factors were revealed during both geochemical and the Irtysh River basin analysis. These man-made effects negatively affect the touristic activity in the region. As it is known, there is strong relation between environmental condition and touristic perspectives (Ilieş et al., 2017). So, the research conducted emphasize necessity of governmental intervention into the finding of solutions of the prevailing environmental situation in Pavlodar region. The challenge is very complicated also because of the importance of the studied region as an industrial hub of the Republic of Kazakhstan.

\section{REFERENCES}

Badiali, F., Ilieş, D. C. \& Castaldini, D. (2018) A tale of a city, through its urban landscape and cultural heritage in the heart of Europe: The case study of Oradea city (Romania). Geojournal of Tourism and Geosites, no. 1, vol. 21, p. 88-102.

Berdenov, Z., G., Atasoy, E., Mendybayev, E., H., Ataeva, G. \& Wendt, J., A. (2016). Geosystems geoecological assessment of the basin of rivers for tourist valorization. Case study of Ilek river basin. Geojournal of Tourism and Geosites, no. 2, vol. 18, p. 187-195.

Berdenov, Z., Mendibaev, E., Salihov, T., Akhmedenov, K. \& Ataeva, G. (2017). Geoecological analysis of industrial cities: On the example of Aktobe agglomeration. Chemistry, no. 6, vol. 26, p. 890-902. 
Bobylev, A., V., Bubin, M., N., \& Rasskazova, N., S. (2016). The Geoecological Modelling of Small Water Reservoirs and River Catchment Areas as a Procedure in Urban Development. in Procedia Engineering, vol. 150, p. 2067-2072. DOI:10.1016/j.proeng.2016.07.240

Dzhanaleyeva, K., Mazhitova, G., Zhanguzhina, A., Berdenov, Zh., Bazarbayeva, T. \& Atasoy, E.. (2017). Technogenesis of geoecological systems of Northen Kazakhstan: progress, development and evolution. Chemistry: Bulgarian Journal of Science Education, no. 6, vol. 26, p. 903-921.

Grizzetti, B., Liquete, C., Pistocchi, A. et al. (2019). Relationship between ecological condition and ecosystem services in European rivers, lakes and coastal waters. Science of the Total Environment, vol. 671, p. 452-465. DOI:10.1016/j.scitotenv.2019.03.155

Ilieş, D., C., Baias, Ş., Buhaş, R., Ilieş, A., Herman, G., V., Gaceu, O., Dumbravă, R. \& Măduţa, F., M. (2017) Environmental education in protected areas. case study from Bihor County, Romania. Geojournal of Tourism and Geosites, no. 1, vol. 19, p. 126-132.

Kabiyev, Y., S., Berdenov, Z., G., Dzhanaleeva, K., M., Atasoy, E. \& Wendt, J., A. (2018). Landscape ecological analysis of the modern delta of the Ural (Zhayik) river. Geojournal of Tourism and Geosites, no. 3, vol. 23 , p. 644-655.

Khomyakov, D., M. (2011). Soil degradation: causes, effects, ways to reduce and eliminate. Moscow, MSU, p. 272.

Mendybayev, E., H., Atayeva, G., Berdenov, Zh. \& Atasoy, E. (2015). Geochemical researches of region soil with technogenic influence in terms of Borlinskiy region, West Kazakhstan. Oxidation Communications, vol. 38, no. 4, p. 1933-1941.

Négrel, P., Ladenberger, A., Reimann, C. et al. (2019). GEMAS: Geochemical background and mineral potential of emerging tech-critical elements in Europe revealed from low-sampling density geochemical mapping. Applied Geochemistry, vol. 111, article no. 104425. DOI:10.1016/j.apgeochem.2019.104425

Nugumanova, L., Frey M., Yemelina, N., Yugay, S. (2017) Environmental problems and policies in Kazakhstan: Air pollution, waste and water. IOS Working Papers, Regensburg, no. 366, 40 p., http://hdl.handle.net/10419/162150

Nworie, O., E., Qin, J. \& Lin, C. (2019). Trace element uptake by herbaceous plants from the soils at a multiple trace element-contaminated site. Toxics, vol. 7, no. 1, article no. 3. DOI: 10.3390/toxics7010003

Perelman, A., I. \& Kasimov, N., S. (1999). Geochemistry of landscape, Moscow, MSU, p. 432.

Pulido-Fernández, J., I., Cárdenas-García, P., J., \& Espinosa-Pulido, J., A. (2019). Does environmental sustainability contribute to tourism growth? An analysis at the country level. Journal of Cleaner Production, vol. 213, p. 309-319. DOI:10.1016/j.jclepro.2018.12.151

Sayet, Yu., V., Revich, B., A., Yanin, E., P., Smirnova, R., S., Basharkevich, I., L., Onishchenko, T., L., Pavlova, L., N., Trefilova, N., Ya., Achkasov, A., I., Sargsyan, S., Sh. (1990) Geochemistry of environment, Moscow, p. 334.

Shaheen, K., Zaman, K., Batool, R. et al. (2019). Dynamic linkages between tourism, energy, environment, and economic growth: evidence from top 10 tourism-induced countries. Environmental Science and Pollution Research, vol. 26, no. 30, p. 31273-31283. DOI: 10.1007/s11356-019-06252-1

Shomanova, Z., K., Safarov, R., Z., Tleulesov, A., K., Nosenko, Y., G., Zhumakanova, A., S., \& Larichkin V., V. (2017). Study of composition of waste from metallurgy production aimed in use them as active phases of catalysts for hydrocarbon raw materials refining. News of the National Academy of Sciences of the Republic of Kazakhstan, Series of Geology and Technical Sciences, vol. 6, no. 426, p. 195-200.

Shomanova, Z., K., Tashmukhambetova, Z., K., Zharmagambetova, A., K., Safarov, R., Z., \& Nosenko, Y., G. (2014). Integrated approach for recycling of ferroalloy production wastes. International Journal of Chemical Sciences, vol. 12, no. 4, p. 1569-1576.

Theng, S., Qiong, X., Ilies, D. \& Dehoorne, O. (2014) Sustainable tourism and ecotourism: Experiences in the lesser Antilles. Advances in Intelligent Systems and Computing, vol. 254, p. 433-445.

Vaganova, O. \& Kovalchuk, O., A. (2012). Assessment of anthropogenic impacts on the landscape and hydrological systems. Geography and natural resources, no. 3, p. 151-156.

*** (2013) PavlodarEnergo, Annual report, 70 p.

*** (2011) Newsletter in the environmental state in the Republic of Kazakhstan for 2011. Astana, RSE "Kazgidromet".

*** (2012) Newsletter in the environmental state in the Republic of Kazakhstan for 2012. Astana, RSE "Kazgidromet".

Submitted: 22.11.2019
Revised:

31.01.2020
Accepted and published online 04.02.2020 